\title{
US Senate votes to overturn research ban
}

\section{Washington}

THE end of three-year-old US ban on federal research using tissue from human fetuses is in sight after the US Senate voted overwhelmingly last week to overturn it.

President George Bush has threatened to veto similar legislation in the past, arguing that fetal tissue research encourages abortion. But the margin of victory in the Senate - 87 to 10 - suggests that the Congress can obtain the two-thirds majority necessary to override a presidential veto. Supporters of fetal tissue research met with White House aides last week to urge Bush not to veto the bill, which will be reconciled with a similar version passed last year by the House of Representatives and then sent to the president.

The vote in the House last July was 274 to 144 . The Senate vote suggests that advocates of fetal tissue research have made considerable progress in the past nine months.

A heavy lobbying campaign for the bill, which is part of a larger measure to reauthorize parts of the US National Institutes of Health $(\mathrm{NIH})$, was led by the
American Federation for Clinical Research (Nature 355, 189; 1992). Supporters were jubilant at the victory. "This represents an excellent example of scientists from academia educating legislators to separate research from politics," says Andrew Hoffman, the federation's president and a Stanford University professor.

The bill also dealt with the controversial question of federal funding for studies on the sexual behaviour of certain populations. An amendment proposed by Senator Jesse Helms (Republican, North Carolina) was adopted that prohibits funding for two surveys - one involving teenagers and one that would sample the US adult population. The surveys became political footballs and were suspended last year after legislators protested that they represented an invasion of privacy. However, a second amendment from Senator Paul Simon (Democrat, Illinois) was also passed that would make such surveys more difficult to kill once they had undergone scientific peer review.

The combination of Simon's amendment and the "research freedom" language

\section{Cabinet reshuffled again}

\section{São Paulo}

THE president of Brazil, Fernando Collor de Mello, has appointed a new secretary of science and technology as part of the most recent upheaval within his Cabinet. The move was greeted positively by the scientific community, which sees the appointment as a promise of increased support.

The new secretary is Hélio Jaguaribe, a sociologist and member of an opposition party. He succeeds Edson Machado, a career bureaucrat with no political ties. Collor's wish to accommodate Jaguaribe's party is expected to extend beyond a seat in the cabinet to providing additional money for science.

Jaguaribe has written a book, Brazil: Reform or Chaos, about the threat to the country from the enormous disparity between rich and poor. Some members of his party, the social democrat $\mathrm{PBDB}$, have refused to cooperate with Collar, but Jaguaribe has discussed this subject and other issues with him.

The director of the Latin American Federation of Physics Societies, Gil da Costa Marques, praises his "independence". But the consensus view is one of cautious optimism. "I hope it means change", says Paulo Milton Barbosa Landim, the rector of São Paulo State University. Referring to his displeasure at the current level of government support for research, Landim added, "the last secretary did not do a good job."
The reshuffling, which so far has involved eight Cabinet ministers, furthers strengthens the hand of Machado's predecessor as science secretary, physicist José Goldemberg. Goldemberg was promoted last year to Minister of Education, and last month took on the additional job as environmental secretary after the dismissal of José Lutzenberger (see Nature 356, 278; 1992). A last-minute appointment after Collor took office in March 1990 , Goldemberg has since become a member of the president's inner circle of advisors.

Goldemberg was in New York last week when the latest changes were announced. He was looking for money for environmental projects in his country, something that Lutzenberger was unwilling to do. In fact, Lutzenberg was fired for telling the industrial world not to lend money to Brazil for conservation projects because it might end up in the hands of corrupt politicians. He said that problems existed even within his own agency for environmental protection, the Brazilian Institute of the Environment and Natural Renewable Resources.

Although Lutzenberger refused to provide names, the charges appear to have substance. Last week, for example, the institute's office in Rio de Janeiro was asked to explain how a 'farm' it had purchased to extend a natural preserve is actually located under the Atlantic Ocean.

Ricardo Bonalume of the fetal tissue portion of the bill will set up an approval mechanism for sex surveys that should limit future political meddling, predicts Howard Silver, president of the Consortium of Social Science Associations. "The existing proposals, as we know them, are dead," he says. "But they can be reintroduced and should do much better under the new mechanisms."

On the eve of the vote, Senator Mark Hatfield (Republican, Oregon) took aim at both the biotechnology industry and NIH with a proposal to prohibit patents on any part of the human body and to impose a three-year moratorium on patenting genetically engineered animals and organisms while a new biomedical ethics board evaluated the implications of such patents. Beyond ethical and safety concerns about genetically engineered organisms, Hatfield questioned NIH's recent patent filing for thousands of human cDNA sequences. After being lobbied intensely by industry and the Bush administration, Hatfield agreed to introduce and then withdraw the amendment in exchange for a future hearing on the gene patent issue by the patent subcommittee of the Senate Labor and Human Resources Committee. The bill now also asks the congressional Office of Technology Assessment to prepare a report on the subject.

Christopher Anderson

UK HIGHER EDUCATION

\section{Faraday, Newton... and Parnaby?}

THE name of Parnaby has joined those of Newton and Faraday as titles for centres of excellence designed to revitalize the training of graduate scientists and engineers in the UK.

The Parnaby centres would play host to the revamped engineering doctorates announced last week by the Science and Engineering Research Council (SERC). Named after John Parnaby of Lucas Applied Technology, who headed the SERC working party set up to revise the UK's engineering doctorates, they are seen as having a role parallel to the Faraday Centres and Newton Institutes that have been proposed by various political bodies ( $\mathrm{Na}$ ture 355,757 ; 1992). All are loosely based on the German Fraunhoffer Institutes.

The current system of training engineers in Britain is seen as not meeting the needs of the manufacturing industry. The new doctorates will last four years instead of the customary three, and will combine close industrial cooperation, courses in a range of subjects and training in management techniques. The SERC will support three pilot studies, each with 10 students, to test the idea.

Ian Mundell 